\title{
Conjunctival Melanoma Pathologic Primary Tumor TNM Finding v8
}

National Cancer Institute

\section{Source}

National Cancer Institute. Conjunctival Melanoma Pathologic Primary Tumor TNM

Finding v8. NCI Thesaurus. Code C140583.

A pathologic finding about one or more characteristics of conjunctival melanoma,

following the rules of the TNM AJCC v8 classification system as they pertain to staging of the primary tumor. 